\title{
BÁRDOS-FÉLTORONYI MIKLÓS: BEVEZETÉS A GEOPOLITIKÁBA
}

\author{
(L'Harmattan Kiadó, Budapest, 2006, 254 o.)
}

\section{BUSA CSILLA}

A geopolitika a társadalomtudományok egyre divatosabbá váló, bár még kevéssé közismert tudományága, olyan terület, amivel egy kicsit mindenki foglalkozik legfeljebb nem tud róla. Geopolitikai kérdésekkel szembesül az újságolvasó, amikor gázvezetékek építésérỏl, nagyvállalatok terjeszkedéséről olvas, de nem kerüllheti el a geopolitikai vonatkozásokat akkor sem, amikor terrorizmusról, háborúkról, vallási konfliktusokról, vagy éppen nemzetközi kapcsolatokról, diplomáciai kérdésekról szóló cikk kerül a kezébe.

De mi az a geopolitika (vagy inkább geopolitológia)? Mitöl geopolitológus egy geopolitológus? Miért hasznos, mire használható a geopolitika? Bárdos-Féltoronyi Miklós Bevezetés a geopolitikába címú könyve választ ad e kérdésekre.

A mủ címe árulkodó: a „bevezetés” kitétel jelzi, hogy a geopolitikával ismerkedők jó helyen járnak. Állíthatjuk ezt nemcsak azért, mert a kötetből bárki - legyen társadalomtudományokkal foglalkozó szakember, katona, diplomata, egyetemista, vagy éppen csak érdeklödő, a világban nyitott szemmel járó polgár - elsajátíthatja a legfontosabb geopolitikai alapismereteket, hanem azért is, mert mindezt egy olyan „vezetővel” teheti meg, aki komoly tapasztalatokkal rendelkezik a téma oktatása terén. A geopolitika iránt érdeklödő „,kezdőknek” sokáig nem volt könnyủ dolguk, Bárdos-Féltoronyi munkája ugyanis hazai viszonylatban hézagpótló mủ. A könyvet elsősorban felsőbb éves egyetemi hallgatók számára ajánlja a szerző - gyakorlatilag tankönyvként -, de úgy véli, elolvasása mások (pl. diplomáciával, geogazdasági kérdésekkel foglalkozók stb.) számára sem haszon és tanulság nélküli.

A könyv annak ellenére, hogy a „bevezetés” címet viseli, nem szokványos „,bevezető" munka, nem célja ugyanis a geopolitika bonyolult kérdéseinek részletekbe menö vizsgálata. A mü nemzetközi viszonylatban tárgyalja a geopolitikai fogalmakat és összefüggéseket, s teszi mindezt egyfajta kritikai attitüddel. A szerző célja ezzel a legszükségesebb geopolitikai ismeretek átadása mellett elsősorban az, hogy megalapozza, elösegítse a geopolitikai gondolkodáshoz szükséges szemléletmód kialakulását.

A 254 oldalas kötet öt fejezetre tagolódik, melyeket egy rendhagyó bevezetés elóz meg. Az Elöszó és alapvetések címủ bevezetö fejezet ismerteti a könyv céljait, felvázolja tartalmát, szerkezetét, majd egy előzetes, rövid definícióval tisztázza, hogy mit takar a geopolitika fogalma. (Bárdos-Féltoronyi megjegyzi, hogy geopolitika helyett helyesebb lenne geopolitológiáról beszélni, de mivel a geopolitika kife- 
jezés terjedt el, ezért a továbbiakban ezt a megnevezést alkalmazza.) A bevezetés érdekességét és rendkívüliségét az ún. alapvetések adják. A szerző maga hívja fel a figyelmet arra, hogy az általa írott könyv csak egy lehetséges változata a geopolitikai bevezetéseknek, meggyőzödése ugyanis, hogy a személyes élettörténet hatással van az emberek beállítottságára, gondolkodásmódjára, sőt, bizonyosfajta elfogultságot is von maga után. Elfogultságaink ellen azonban alapfeltevéseink ismertetésével és a tárgyilagosságra való legteljesebb mértékü törekvéssel küzdhetünk, s így állításaink, következtetéseink megtárgyalhatók és megvitathatók lesznek. Hogy beállítottságával és nézeteivel kapcsolatban ne legyenek kétségeink, a szerző közreadja rövid életrajzát, így már a bevezetőben magyarázatot kapunk a könyv Európa szempontúságára és a szerző USA-val kapcsolatos nézeteire is.

Az előszót követő öt „lényegi” fejezet a geopolitika definiálása után áttekinti a 20. századi geopolitikai tanokat, majd rátér a geopolitika szereplőinek (intézmények, államok, nemzetközi szervezetek stb.) bemutatására, amit a meghatározó tényezök és tétek elemzése követ. A sort a geostratégiáról szóló befejező fejezet zárja.

De kezdjük az elején, azaz térjünk vissza a kiinduló kérdéshez: mi is az a geopolitika, miért fontos elemezni és megérteni, azaz mi a geopolitika lényege? A geopolitika a hatalom különbözỏ színtereivel, időbeli mozzanataival és erötereivel foglalkozik; a hatalom és a tér viszonyát vizsgálja, ahol szereplők, játszmák, tétek és tényezők vannak jelen. A geopolitika által vizsgált tér lehet földrajzi, szellemi, vallási vagy akár a képzeletben létező tér is. Mivel társadalomtudományról van szó, a geopolitika szükségképpen szól a tér, az egyén és a társadalom kapcsolatáról erre utal Bárdos-Féltoronyi „nyelvújitása”, a térlét kifejezés is. Térről nem beszélhetnénk társadalom nélkül, ugyanakkor a társadalmi lét sem képzelhetô el tér nélkül. Tér viszont nem képzelhetö el idő nélkül, a geopolitika ezért a hatalom és az idö kapcsolatát is vizsgálja. Az idö tényezöje azért fontos, mert a hatalmi viszonyok változásai miatt mind a tétek és tényezök, mind a geopolitikai szereplök hatalmi helyzete folyamatosan változik, állandó mozgásban van.

A geopolitilógus tehát alapvetôen a térrel foglalkozik, amikor a hatalmi eróviszonyokat vizsgálja. De mi különbözteti meg a hasonló területtel foglalkozó katonától vagy diplomatától? És ha ennyi rokon terület van, mi szükség van még a geopolitikára is? Geopolitikai kérdéseket valóban csak összetett módon - katonai, diplomáciai, földrajzi ismereteket figyelembe véve - lehet elemezni, a geopolitikát és a geopolitilógust azonban a használt módszerek különböztetik meg a hasonló témával foglalkozóktól. A diplomata célja a sikeres tárgyalás, míg a katonáé a cselekvés, a hadmúveletek, a fegyverekkel vívott geostratégia kidolgozása. A geopolitilógus ezzel szemben elemez, magyaráz, értelmez, azaz a geopolitika - mint minden társadalomtudomány - a megértésre, a magyarázatra és az értelmezésre helyezi a hangsúlyt. A geopolitikai elemzés tehát nem más, mint a hatalom térbeli és időbeli jelenségeinek feltárására és tanulmányozására szolgáló eszköz. A szerzönek ugyan nem célja, hogy könyvében geopolitikai módszertant dolgozzon ki, de a geopolitikai elemzés sajátosságainak megismeréséhez szükséges mélységig kitér a „miként” problémájára is. 
Geopolitikai bevezetés nem képzelhető el a legjelentősebb geopolitikai irányzatok bemutatása nélkül, a második fejezet ezért a 20 . század tudományos geopolitikai hagyatékát tekinti át röviden. Bárdos-Féltoronyi nem tüzi céljául, hogy kidolgozza a geopolitikai tanok fejlődésének történetét - kizárólag csak azokat a geopolitikai tanokat ismerteti (liberalizmus, konzervativizmus, szocializmus, nacionalizmus, populizmus, vallási fundamentalizmus), melyek a 20. század folyamán az északatlanti térségben, kimondottan az ủj tudomány területén kutató szerzők tollából származnak. Ez utóbbi kitétel pedig akkor teljesül - azaz akkor tekinthetó valaki a geopolitika tudományos múvelöjének -, ha a hatalom és a tér együttes távlatában gondolkodik.

A különböző világnézetek, az előfeltételezések és a kialakított fogalmi rendszerek meghatározzák a geopolitikai elemzések föbb iskoláit is. Az örök békét óhajtó liberálisok geopolitikai vágya például egy, az államok közötti háború lehetőségét kizáró világszövetségi állam. Ennek elérésében a szabadelvüek kiemelkedő szerepet szánnak a diplomáciának, mint olyan eszköznek, amely által megteremthetök az egyensúly-politika nemzetközi feltételei, azaz a nemzetközi jog. A gazdasági (neo)liberalizmusra jellemző államellenesség ugyanakkor erőteljesen megnehezíti a nemzetközi gazdasági kapcsolatok szabályozását.

A konzervatívok ezzel szemben célul tủzik ki, vagy legalábbis elfogadják a hatalom végsőkig való kihasználását, így a liberálisokkal ellentétben alapvetỏen háborúpártiaknak tarthatók. A különböző kultúrákat és civilizációkat egymástól gyökeresen eltérőnek tartó neokonzervatív elkẻpzelések a fundamentalizmus egyfajta modern, világi változatának tekinthetök, a (neo)konzervativizmus geopolitikája pedig tulajdonképpen a nagyhatalmi erőszak igazolása, illetve eszköze - állítja a szerző.

A geopolitikai jellegü társadalmi képzetek azokból az elképzelésekből és eszmékbỏl táplálkoznak, amelyeket a különböző csoportok saját és szomszédaik helyzetéről kialakítanak. A vallási ideológiák e szempontból olyan témák szervezett együttesét alkotják, amely a politikai viselkedésformák összefüggésében is értelmezhető. A (vallási) fundamentalisták, a népszerüség-hajhászó, gátlástalanul ígérgető populisták és a nacionalisták is masszív ellenségképpel rendelkeznek, és további közös jellemzőjük, hogy a megoldatlan társadalmi problémákat háború kirobbantásával akarják kezelni.

Érdekes színfoltot jelent az ún. „zöldek" által képviselt, egyértelműen békepárti irányvonal. A ,zöldek" nagy fontosságot tulajdonítanak a magánérdekeltségtől független civil szervezeteknek a jelenlegi, nem eléggé hatásos képviseleti demokrácia új esélyei és lehetőségei megteremtésében. Hisznek abban, hogy a tömegkommunikáció révén egyre könnyebb lesz az ellentmondásos egyéni és társadalmi képzetek terjesztése, melyek így geopolitikai tényezőkké válnak. A geopolitikai ismeretek hozzảjárulnak a háborúk elkerüléséhez, mivel a nyílt geopolitikai tájékoztatás és vita mozgósítja a civil szervezeteket, akiknek lehetőségük nyilik a geostratégiai döntések befolyásolására, ezáltal sokat tehetnek a háborúk kitörésének megakadályozásáert. 
A geopolitikai tanok áttekintése után tér rá a könyv a hagyományos geopolitikai ismérvek, tényezők és tétek, illetve eszközök és érdekek elemzésére. A legfontosabb geopolitikai tényezők vagy tétek közé tartoznak - többek között - a földrajziéghajlati feltételek, az országok és határaik, a népesség, a katonai erö, a nyersanyagok, az erőforrások, az utak, a vezetékek, a mủszaki fejlettség - és a sort sokáig lehetne folytatni, hiszen földrajzi, politikai és történelmi helyzettől függően tulajdonképpen bármi lehet geopolitikai tényezö vagy tét. A tényezők vagy tétek nemcsak fizikai, anyagi síkon jelennek meg a geopolitikai színtéren, hanem az egyéni és a társadalmi képzelet szintjén is. A geopolitikai tényezök legtöbbször geostratégiai tétek is, azaz feltételei a hatalomnak, miközben megszerzésük önmagában is cél. A tétek és tényezők adottság jellegének fenntartása vagy éppen módosítása miatt a geopolitikai színtér állandó változásban van, a különböző szereplök helyzete változó. Sok geopolitológus - szemben a szerzővel - a fizikai adottságoknak meghatározó szerepet tulajdonít, Bárdos-Féltoronyi viszont azt az álláspontot osztja, miszerint a hatalomnak lehetősége van adottságai, terei megváltoztatására. Ráadásul felhívja a figyelmet arra is, hogy ugyanannak a tényezőnek más súlya van a „világközpontokban” és a „peremvidékeken”, ami az egyiknek létszükséglet, az a másiknak értéktelen lehet.

A geopolitikai színtér folyamatos változását jelzi, hogy a Föld a történelem folyamán már sokféleképpen volt felosztva - az időben és a térben egyaránt. A geopolitológusok az adott helyzet értékelésekor szükségképpen vizsgálják a földrajzi adottságok előnyeit és hátrányait (pl. mekkora az ország területe, milyen a fekvése és az alakja; milyenek az éghajlati feltételei; milyen természeti kincsek találhatóak az adott területen; hány kikötővel, repülötérrel rendelkezik; áthalad-e rajta gázvezeték; melyek lennének az ország ideális határai stb.). A geopolitológus azonban nem elégedhet meg az egyszerú leírással, komplex elemzést kell nyújtania. (Hogy mindenki számára világos legyen, hogyan is kell ezt csinálni, BárdosFéltoronyi bemutat néhány rövid elemzést egy-két problémakörben.)

A határok kérdése központi téma a geopolitikában. Ahogy arról már volt szó, a geopolitika az anyagi valóság mellett fontos tényezöként számol a szellemi, eszmei, kulturális és érzelmi összetevökkel is. A határok példájánál maradva: a határoknak lehet történelmi-földrajzi eredete, nemzeti jellege, de az is megeshet, hogy csak a képzeletben léteznek. Márpedig annak, hogy mit gondolnak az emberek egy ország határairól, komoly politikai jelentősége van. Az ideális határokkal kapcsolatos elképzelések a múlt egyes elemeinek a jelenből kiinduló „felélesztései”, ez a „felélesztés” azonban csak azokat az elemeket érinti, amelyek összhangban állnak a jelenlegi politikai célokkal. (Hogy a saját portánkon söpörjünk, gondoljuk csak a nagy Magyarország visszaállitását kívánó szélsőséges politikai erőkre és követeléseikre.)

A határok mellett a nyersanyagok és erőforrások, illetve az ezekhez való hozzáférés is kiemelkedően fontos geopolitikai tényezö, a nyersanyagokhoz való hozzáférés és azok ellenőrzése ugyanis alapvetö geostratégiai cél. Sokakat aggaszt az a tény, hogy a termelő és a fogyasztó országok között kölcsönös függöség alakulhat ki, de Bárdos-Féltoronyi rámutat arra, hogy egy geopolitológus ennél árnyaltabban 
gondolkodik: az egész Európát behálózó gázvezetékben például nemcsak a függőséget kell látni, hanem azt az elönyt is, hogy jelentös mértékben csökkenti egy európai háború kitörését. Hasonló komplex gondolkodásmódot kiván a geopolitika más tényezők esetében is. A gáz- és kőolajvezetékek, -hálózatok mellett az országutak, vasutak, légi ưtvonalak elfoglalásáért, ellenőrzéséért, használatáért vagy tönkretételéért folytatott küzdelmek is a geopolitikai viszályok tipikus példái. Tény, hogy a világban - különösen Eurázsiában - az elmúlt évtizedekben óriási fejlesztés zajlott le az országutak, vezetékek és légi útvonalak tekintetében, a szerző pedig felhívja a figyelmet arra, hogy a tényeknek többféle értelmezése is lehetséges -, azaz e fejlesztések az aránylag békés együttműködés jeleiként is értelmezhetők, de azt is jelezhetik, hogy egy közelgő háborúra való felkészülés zajlik a szemünk elött.

Kétség sem fér hozzá, hogy a katonai ütöképesség az egyik legfontosabb geopolitikai tényező. Itt nemcsak a nukleáris fegyverek birtoklását és a klasszikus fegyvernemekkel való felszereltséget kell számításba venni, hanem az egyes országok védekező vagy támadó szándékát, a szárazföldi és tengeri határok hosszát és jellemzöit, a hadseregek képzettségét, felszerelését, a katonai biztonságról alkotott elképzeléseket stb. Neheziti az erőviszonyok felmérését és reális megítélését, hogy az egyes tényezők értékelése relativ, függhet például a hatalmon lévők értékelésétől, véleményétől is. Mindezek mellett még számos körülmény van, melyek bonyolítják a helyzetet. A „nemzeti felszabadíto” és gerillacsapatok erejének felmérése például igencsak nehézkes, $\mathrm{s}$ ugyanez mondható el a terrorista csoportokról is. Ezek száma legfeljebb néhány százra tehetö, és Bárdos-Féltoronyi szerint velük kapcsolatban háborúról beszélni nevetséges - ugyanakkor veszélyes is, mivel ürügyet szolgáltathatnak tényleges háborúk kirobbantásához.

Napjaink és a közelmúlt világpolitikai eseményeit tekintve (különösen, ha maradunk a terrorizmus kérdésénél) könnyủ belátni, hogy a hírközlés és a tömegtájékoztatás csatornái feletti uralom szintén fontos tényezöje a geopolitikának. Nem mindegy ugyanis, hogy mi folyik ezeken a csatornákon (lásd: a demokratikus országokban a szabad tömegtájékoztatásért folyó küzdelem mindennapos). Mivel a tömegtájékoztatás nem „légüres” térben történik, ezért mindazt, amit látunk, hallunk, az elbeszélö értelmezése alapján ítéljük meg. A sokoldalú tájékoztatás lényege, hogy a valóságra épül, olykor ellentmondásos, gondolkodásra késztet és a józan észre igyekszik hatni. A legtöbb geostratégiai beszédnek, retorikának vagy propagandának ezzel szemben van ugyan némi kapcsolata a valósággal, de sem tényszerúségre, sem ésszerüségre nincs szüksége. Célja, hogy meggyözzön és mozgósítson, ezért elsősorban a képzeletre, az érzelmekre és az indulatokra hat. A geostratégiai beszédben, retorikában vagy propagandában a „nem anyagi” momentumok nagy jelentőségủ tényezőkké és tétekké válhatnak, mivel a retorika képes meggyőzni az embereket, hogy az ellenfeleket vagy a másként gondolkodókat ellenségnek lássák.

A geopolitika legfontosabb tényezői közül mindenképpen szükséges még megemlíteni a nemzetközi intézményes-diplomáciai kapcsolatok hagyományát és kimunkáltságát. Bárdos-Féltoronyi szerint a háború és a béke között a legnagyobb különbség, hogy míg a háború az elbeszélések különbözőségén alapul, addig a békében a 
felek a tárgyalásokon keresztül közelítik egymáshoz elbeszéléseiket. A diplomácia eszközei tehát eltérnek a konfliktusok háborús megoldásától: a diplomata képvisel, megfigyel, befolyásol és tárgyal. A modern diplomácia azonban már nemcsak az egyes államok önérdekeit, hanem a világrendszer közös érdekeit is szem elött tartja.

A tétek és tényezők bemutatásához és a téma fontosságához mérten meglehetősen röviden foglalkozik a könyv a geopolitika szereplöivel. A geopolitikai elemzések egészen közelmúltig csak az állammal és az állam intézményeivel, illetve az állami kereteken belül megszerveződő közhatalommal foglalkoztak, a fejlődés azonban szükségképpen kitágította az ilyesfajta elemzés kereteit. Geopolitikai szereplök lehetnek tehát a hagyományos nemzetállamok mellett az egyházak, a nemzetközi nagyvállalatok, a politikai szervezetek, a civil társadalmi intézmények, testületek, egyesületek stb. A kötet a szerző által meghatározott fontossági sorrendben tárgyalja a különböző intézményes szereplöket, de ezek közül is csak a legfontosabbakat. Leghosszasabban az államokkal és államközösségekkel foglalkozik, és eközben igyekszik tisztázni bizonyos, sokak által helytelenül használt fogalmakat (pl. állam, ország, nemzet). A könyvben olvasható meghatározás szerint az állam szervezett és intézményesitett társadalmi és hatalmi építmény, a magán- és/vagy közösségi, társadalmi szervezetek összessége egy ország területén, és - geopolitikai szempontból - legfontosabb szerepe, hogy közremüködjön a különböző geopolitikai térjelenségek törvényesítésében. Az államok bizonyos közös célok elérése érdekében gyakran szövetkeznek egymással, és ezek az államközösségek céljuk és egyéb jellemzőik szerint többfélék lehetnek. Céljuk lehet katonai vagy gazdasági együttműködés, az összekapcsolódás pedig lehet laza kötelék, vagy szoros összetartozás. BárdosFéltoronyi véleménye szerint mind a mai államok, mind pedig az államközösségek egyik legfontosabb feladata a magántulajdon megörzése és védelme a fennálló tőkés rendszerben annak állandósítása céljából.

A könyv az Európai Uniót, mint az államközösség legjellegzetesebb példáját, külön elemzi. Az EU megalapítása alapvetően geopolitikai természetủ volt, és politikai jellege egyre erőseb lesz. Az EU a 21. század eleji világhatalmak közé nőtte ki magát - annak ellenére, hogy gyenge pontjaként szokták említeni az egységes és sikeres külpolitikai cselekvés hiányát. A csatlakozási tárgyalások és a bővítések azonban jelzik, hogy az EU-nak vannak sikeres nemzetközi lépései is, és az összeurópai külpolitika keretében korábban született kezdeményezések is lassan „beérnek", eredményeket produkálnak. Az EU tárgyalása keretében a szerző kitér az Európa Tanács (ET) és az Európai Biztonsági és Együttműködési Szervezet (EBESZ) mint nemzetközi színtéren is mértékadó szervezetek bemutatására. Az ET és az EBESZ jelentőségét Bárdos-Féltoronyi abban látja, hogy tagja Oroszország, mely állam más kiemelkedő politikai vagy diplomáciai szervezetben nem rendelkezik tagsággal az európai térségben. Az EBESZ tehát az EU számára biztosítja a Brüsszel-Moszkva-tengely múködését, míg a Brüsszel-Washington-tengely múködése a NATO-n keresztül érhető el. 
A NATO szerepe napjainkban már önmagában is érdekes kérdés. A hidegháború és a Varsói Szerződés ma már történelem, a NATO azonban létezik, és vezetése teljes egészében amerikai kézben van. A szerzö szerint - miután minden parlamenti jóváhagyás nélkül egyszerủen feljogosította magát a „területén kívüli” katonai beavatkozásra - a NATO már nem tekinthető védelmi államszövetségnek. Hiába vélik azonban sokan úgy, hogy a NATO már csak azt a célt szolgálja, hogy az USA Európát katonailag ellenőrizze, és időnként felhasználja katonai akcióihoz, az EU-nak mégis szüksége van a NATO-ra. Ez ugyanis az egyetlen intézményesített kötelék az Atlanti-óceán két partja között, ami által szervezett formában lehet csökkenteni a viszályok elmérgesedésének lehetőségét, továbbá a döntéseket egyhangúlag kell elfogadni, ami a kis államok számára lehetőséget biztosít a számukra hátrányos tervek elleni fellépésre.

Az egyéb nemzetközi szervezetek bemutatása a kötetben már rövidebb, egyedül az ENSZ és a legfontosabb pénzügyi szervezetek szerepének és jelentőségének tárgyalása történik részletesebben. Az ENSZ a diplomácia egyik nélkülözhetetlen intézményévé vált az elmúlt évtizedekben, egyes szerveinek múködésével azonban vannak problémák. Üdvözlendő fejlemény a római Nemzetközi Büntető Bíróság felállítása, ugyanakkor az ENSZ alapszabálya által elöírt nemzetközi rendőrség létrehozása még mindig várat magára, pedig már csak a sokat emlegetett „nemzetközi terrorizmus" elleni harc miatt is szükség lenne rá, ahogy egy nemzetközi ügyészségre is. Mindezek mellett a világbéke fenntartása szempontjából alapvető szükség lenne a több milliárdos lakosságú szegény országok fejlesztésére is - véli a szerző.

A Nemzetközi Valutaalap az egyik legfontosabb nemzetközi pénzügyi szervezet, melynek papírforma szerinti célja a nemzetközi pénzügyi rendszer fenntartása. Bárdos-Féltoronyi szerint azonban tényleges feladata nem más, mint biztosítani, hogy az amerikai dollár legyen a világ pénzügyeinek első számú fizetőeszköze, $\mathrm{s}$ hogy az USA eladósodása ne vonjon maga után visszafizetési kötelezettséget. A Nemzetközi Valutaalap létjogosultságát az is megkérdőjelezi, hogy valójában nem része az ENSZ intézményrendszerének, mert döntéseiben nem érvényesül az egy ország egy szavazat elv.

Bárdos-Féltoronyi szerint a Világkereskedelmi Szervezettel kapcsolatban is számos probléma említhető: pl. a magánjogú, a nagyhatalmak és nemzetközi nagyvállalatok befolyását szolgáló szervezet nemcsak a demokratikus elveknek, hanem a nemzetközi jognak is ellentmond, továbbá az ENSZ intézményes rendszerén is teljes mértékben kívül áll. Az azonban nem vitatható el a Világkereskedelmi Szervezettől, hogy általa a történelem során elöször a világkereskedelmi együttmüködést szabályozott és intézményesített formában bonyolítják, és kezelik a konfliktusokat. A Világkereskedelmi Szervezet egyébként szemléletes példája a magánosítási folyamatok terjeszkedésének is. A geopolitikai elemzések kiterjesztésére a nagyvállalatok szerepének erősödése miatt is szükség volt, ami a tőketömörítés, illetve a nagyhatalmak és nagyvállalataik egyre szorosabb együttmüködésének a következménye. Az egy-egy iparágat világszinten uraló nemzetközi nagyvállalatok (és velük karöltve a magánbankok) napjainkban már nagyobb tekintéllyel rendelkeznek, mint a világ legjelen- 
tősebb országai. Az állam pedig, mivel nem tudja irányítani a magánvállalati termelést, bizonyos mértékig kiszolgáltatott. Komoly geopolitikai kockázatot jelent, ha a vállalatok nemzetközivé válása gyorsabb ütemben halad, mint a nemzetközi intézmények és államszövetségek kiépülése.

A geopolitikai szereplök közül a civil társadalmi szervezetek, a nemzetközi nem állami szereplők bemutatása a legrövidebb a kötetben. A népek, nemzetiségek, vallási, ideológiai mozgalmak - ha sikerült eljutniuk az intézményesedés bizonyos fokára - önmagukban is lehetnek geopolitikai szereplök, és a 20. század második felében színre lépö civil szervezetekkel is számolni kell már nemzetközi téren. A szerző e nemzetközi geopolitikai szereplők sajátosságait konkrét példákon, az egyházakon keresztuil világitja meg.

A geopolitika szereplőinek sorába és bemutatásába sok más szereplöt is be lehetett volna vonni. Jogosan merül fel például a kérdés, hogy vajon a uralkodó osztály, mint jelentős hatalommal rendelkező csoport, nem tartozik-e a geopolitikai szereplök körébe. Bárdos-Féltoronyi - bár megjegyzi, hogy a nagyvállalatok, bizonyos pártok, és olykor bizonyos egyházak vezetö körei egy nemzetközivé vált uralkodó elitté formálódtak - az elitet nem tekinti geopolitikai szereplönek, véleménye szerint az elit újratermelődése a szociológia ,asztala”. A fejezet azonban nem törekedett a teljességre, csak azokat a szereplöket minősitette vizsgálatra érdemesnek, amelyeknek döntö és tartós befolyásuk van geopolitikai téren. Másrészt a szerző úgy véli: a geopolitikai gondolkodás bemutatására elegendő egy-két eset bemutatása is.

A befejező, geostratégiáról szóló fejezet, - hogy a szerzőt idézzük - a könyv „legmegeröltetöbb" része. A geostratégia célja a kockázatok mérlegelésével a biztonság megteremtése. A geostratégia tulajdonképpen egy játszma - a cél megvalósítása egy tét vagy egy tényező megszerzése által az együttmüködés és a viszály dialektikus játszmájának keretében. Mivel szinte mindig egyedi esetről van szó, ahol helyzeteket, állapotokat, kockázatokat stb. kell felismerni, téteket és tényezöket kell azonosítani, ezért az általánosítás nehézkes. Ez a fejezet a „miért”, „milyen módon”, „hogyan" kérdések vizsgálatával igyekszik választ adni arra, hogyan határozható meg a legjobb geostratégia a különbözỏ szereplök számára. A szerző kigyüjti az eddigi fejtegetésekből azokat a példákat, amelyek taktikai vagy stratégiai döntésekröl szólnak, hogy szemléltesse a geostratégiai játszmák sokféleségét, majd a továbbiakban esettanulmányokat közöl annak érdekében, hogy bemutassa: miként lehet egy döntést elemezni, egy helyzetet megoldani, számításba véve minden fontos geopolitikai tényezőt. Elöször felvázol egy együttmüködés- és viszálytant, amit esettanulmányok követnek, majd visszatér a háború és béke elméleti kérdéseire.

A fejezet utolsó témája a világ hatalmi rendszerének európai szempontú elemzése. Bárdos-Féltoronyi a korrektség jegyében jelzi: az általa adott elemzés csak egy kísérlet, mivel a nemzetközi eröviszonyokat számos olyan tényezö is erösen befolyásolja, melyeket nagyon nehéz megbecsülni és értékelni (pl. új államszövetségek jönnek létre, melyek geostratégiája még csak most van kialakulóban). A szerzỏ úgy látja, hogy a 21. század elején a világ hatalmi rendszerének átalakulása zajlik, amit nagy valószínüséggel az USA nagyhatalmi státusza fog megsínyleni. Ma a világ 
Tér és Társadalom 21. évf. 2007/4. 213-234. p.

nagyhatalmai az EU, az USA, Kína és Oroszország. Az USA tehát még mindig erős, de már az intő jelek is megfigyelhetők (pl. az euró kezdi helyettesíteni a dollárt a nemzetközi pénztartalékokban; az USA eladósodott, energiaigénye jelentős stb.) A 21. század elején kialakuló négyhatalmi rendszer veszélye, hogy bizonytalanabb, kockázatosabb, mint a hidegháborús kéthatalmi rendszer, de még mindig stabilabb, mint amilyen egy háromhatalmi berendezkedés lenne. Az EU-nak azonban mindenképpen át kell gondolnia biztonság- és védelempolitikáját, $\mathrm{s}$ itt jön a kérdés: mi lenne a legjobb EU-s geostratégia? Bárdos-Féltoronyi álláspontja, hogy Brüsszelnek az Egyesült Államokkal való jó kapcsolat megtartása mellett a jelenleginél nagyobb távolságot kellene tartania Washingtonnal, Moszkvához viszont közelednie kellene, hogy mindkettőtől azonos távolságra legyen. Emellett a szerzö felveti a Kínával kötendő geostratégiai szövetség szükségességét is.

Amint arról korábban már szó volt, a geopolitika a hatalom térbeli és időbeli jelenségeinek feltárására és tanulmányozására szolgáló eszköz, és a könyv elsődleges célja a geopolitikai gondolkodás elsajátításának elősegítése. Többek között e célt szolgálja a kötet függeléke is. A szerző szerint a geopolitológus dolga az, hogy kérdéseket tegyen fel, a felelősségteljes állampolgár-olvasónak pedig az, hogy érveket találjon a különböző értelmezések mellett, és ismeretekkel gazdagítsa azokat. (E munkához a függelék bevezetỏje néhány szempontot is megad.) A függelékben szereplő négy szöveg közül hármat Bárdos-Féltoronyi jegyez, de felhívja a figyelmet arra, hogy ezek az esszék, tanulmányok sokkal személyesebbek és elkötelezettebbek, mint a könyv korábbi fejezetei, így erősen vitathatóak. Érdekes és aktuális témát feszeget a Kérdések az EU biztonsági és védelmi elgondolásáról EU-s és „köztes-európai” szemmel címú szövegben Bárdos-Féltoronyi. A terrorizmus kérdése különböző témák kapcsán több alkalommal is előkerül a kötetben, e tanulmányában azonban új szemszögből vizsgálja a szerző a jelenséget. Bárdos-Féltoronyi szerint a terrorizmus nagyszerú ürügyet szolgáltat a nagyhatalmak számára néhány számukra fontos, de normál körülmények között nehezen kezelhető vagy jelentős ellenállást kiváltó belpolitikai kérdés megoldásához. Így például könnyebben felléphetnek a zavaró kisebbségek ellen és elnyomásukat a terrorizmus elleni harccal indokolhatják. A rendöri intézkedések szigorítását és az igazságszolgáltatás terén végrehajtott különböző korlátozásokat ugyancsak előszeretettel „álcázzák” a terrorizmus elleni küzdelemnek, márpedig ezeknek az intézkedéseknek sokszor egyáltalán semmi közük nincs a terrorizmushoz. Felmerülhet a kérdés, hogy a terrorizmus esetében miért csak az erőszakos cselekmények megelözésére - rosszabb esetben megtorlására - koncentrálnak, és miért nem fordítanak nagyobb figyelmet az erőszak terjedésének megakadályozására, hogy az ebböl szárba szökkenô terrorizmust a gyökereinél lehessen megragadni. Könnyen belátható, hogy az erőszakra erőszakkal reagálás helyett nemzetközi társadalmi-gazdasági együttmúködésre vagy fegyverkorlátozásra is gondolhatnának a nagyhatalmak.

A számos gondolatébresztő meglátást és kérdésfelvetést tartalmazó könyvet részletes, a szerző témához kapcsolódó írásait - könyvek, folyóirat-különszámok, illetve 
cikkek szerinti bontásban - közlö, továbbá hasznos webcímeket is tartalmazó irodalomjegyzék, valamint fogalom- és tárgymutató zárja.

A kötetet - amint azt a bevezetöben jeleztük - tankönyvnek szánja a szerzö. A kötet tankönyv jellegét a legfontosabb fogalmakat, összefüggéseket kiemelö összefoglaló táblázatok, fogalmi áttekintések és ábrák adják. A fejezetek végén szereplő kérdések, feladatok, valamint a megadott magyar, francia, német, olasz és angol nyelvủ szakirodalom is a tanulást szolgálja, és az adott témakörben való elmélyülést segíti elö. Az ismétlések, melyek a korábbi fejezetekböl röviden összefoglalják az adott témához kapcsoló legfontosabb ismereteket, megállapításokat, időnként kissé „tanárossá” teszik a kötetet, bár ez egy tankönyvként is funkcionáló könyv esetében nem igazán vehetö zokon. A „tanárosságot” ráadásul jól oldják az egyes fejezek elején közölt, a szerzỏ éleslátására, kritikai és humorérzékére következtetni engedő idézetek és viccek. Ezek nemcsak „könnyedebbé” és olvasmányosabbá teszik a kötetet, hanem arra is ráébresztik az olvasót: egy-egy történelmi korszak, helyzet, konfliktus megértése szempontjából milyen fontos lehet pl. a szépirodalom, vagy, hogy néha egy találó, a korszak lényegére tapintó vicc hatásosabb lehet a hosszas magyarázatoknál.

A kötet elolvasásának tehát valóban nekivághat bárki, a könnyen követhetö gondolatmenetek, a letisztult stílus, az érthető nyelvezet a geopolitikában és a társterületeken járatlanok számára is lehetővé teszik a geopolitikában való elmélyülést, az aktuális témák felvetésével pedig a szerzỏ mindvégig képes fenntartani az olvasó érdeklődését. 